\title{
Educational Innovation And Personalized Tutoring In Higher Education: A Personal And Professional Guidance
}

\author{
Raúl del Pozo-Rubio, University of Castilla-La Mancha, Spain \\ Pablo Ruiz-Palomino, University of Castilla-La Mancha, Spain \\ Ricardo Martínez-Cañas, University of Castilla-La Mancha, Spain
}

\begin{abstract}
College years determine the essential academic and personal training for students' future success. Certainly, higher education period is essential in the development of students as persons, setting out their emotional and intellectual capital and therefore determining their professional and personal life expectations. However, this process generally must be faced with few help and also sometimes students have to create, sometimes blindly, their own path. In this sense, Social Sciences Faculty of Cuenca (Spain) has created a Tutoring Action Program that is designed to provide more supportive, collegial and discipline-specific training for students. This plan defines also a new tutorial role for professors as personal mentors of students. The aim of this paper is to present the new methodology used for the implementation of the Tutorial Action Plan which includes the assignment of this new role attributed to professors, and that consist in advising and guiding the students in those questions that may arise throughout the university degree, as well as advising students to do those things that are most appropriate for their profiles relative to their future labor orientations.
\end{abstract}

Keywords: Academic Achievement; Personalized Tutorials; Educational Guidance; Tutorial Action Plan

\section{INTRODUCTION}

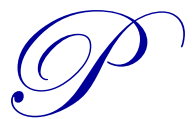

lanning, designing and adopting a comparable degrees system -with a degree structure divided into two main cycles such as degree and master, is part of the European Credit Transfer System (ECTS) that facilitates inter-university mobility of students and that is postulated as the main aim of the European Higher Education Area also known as "Bologna Agreement" (1999) (Feixas, 2004). This agreement suggests a shift in methodology and orientation in the European University teaching scene that changes from a teaching system mainly based on a teacher's lecture to a teaching system based on self-student learning guided by professors. This new teaching path is oriented toward the task of replacing student's traditional role of listener (spectators of the process) to the new role of actors in the teaching-learning process. Therefore, educators can play a role in both a secondary and principal scene, but always through the possession of a more significant guiding weight in the teaching-learning process (Martínez-Cañas et al., 2012).

Due to this new conception of academic teaching-learning process, the students are overwhelmed with the assumption of new responsibilities, whilst they are in a situation of evident lack of enough maturity that don't allow them to be autonomous and self-sufficient (Del Rincón, 2000). According to Del Rincón (2000), they neither possess enough strong will to ask for help in that they do not know what they really need. In addition, the students not only become potential graduates to be trained in this new teaching-learning process scene, but the complexity and competitiveness in the current economic environment, the new social order and the prevailing market system moves them to necessarily have a broader, more complete, autonomous and independent learning. This learning system allows students to complement their traditional and formal college training with extracurricular training oriented to the model new roles that labor market is demanding, and in sum, endues them with sufficient resources and capabilities to survive autonomously. 
Therefore, a tutorial program develops a crucial role for the right and optimal empowerment of college students in the actual Spanish higher education scene. Past tutorial programs were only focused on academic aspects of education and also were mainly based on resolving comprehension related difficulties with specific subjects and that was not enough to satisfy the new needs of students. Students must also acquire some emotional resources such as learning to listen, to trust themselves, to participate and control their own decision making process, to socialize in human groups, to adapt themselves to changing and dynamic situations and environments, to be able to work in groups and lead them, ...(Gairín et al., 2004). All these resources, together with academic ones are so much worthy for their holistic and integral development and training of students, which is still more necessary and demanded by firms in the actual labor market scenario.

Educational methodology used in this innovation process must respond to three major challenges (Huber, 2008): 1) to prepare the next generation of students to fulfill their corresponding roles in the labor market through their optimal and opportune development of their knowledge and skills; 2) to participate in society as an active part of the system; and 3) to assume and enhance their personal responsibilities. Certainly, the competitiveness concept of students is coined as a term that encompasses the traditional concept of knowledge: it truly aims to mobilize knowledge, skills and abilities, which are understood as resources whose mix is adapted and focused to any particular situation (Martínez \& Viader, 2008). Accordingly, if attention required from the student it has a multidisciplinary nature, the appropriate educational plan should follow the same direction. As a rational consequence, traditional tutorials should be reinvented as Tutorial Action Plan (TAP) (Quinquer et al., 2002; Gairín et al., 2003), expanding the traditional academic and formal target to the new ones related to their adaptation to the college, choice of the right subjects and settings of the own curriculum, promotion of self-knowledge, provision of means to address real-life situations, development of techniques for clarifying values, development of cognitive and emotional abilities and skills in order to adapt it to labor market demands (Hernández, 1998; Quinquer et al., 2002; Gairín et al., 2004).

Therefore, classical tutoring, that was attractive in appearance but quite similar to a bureaucratic process was designed solely with an academic background, this problem means that in order to respond and meet the real needs of students, educational innovation activities must overcome two significant problems (Del Rincón, 2000): 1) to design supporting activities that have a look and preserve the individual autonomy of the student, and 2) to make students understand and demand the need for the tutorial action. In addition, teachers' role should change, as it is increasingly required from them to develop their competencies in a way that allows them to combine their knowledge, skills, abilities, cognitive resources and personal capabilities. Accordingly, educator should be more capable to transmit their energy to the students, stimulating changes in them and making them more employable and personal, professional and labor fulfilled (Palomares, 2010). Educators, are not only fountains of knowledge, and must become a good emotional teacher, teaching students to learn, take initiative and know how to meditate and enhance their own decisions (Torrego, 2004). So, good teachers, as perceived by students, should be close with students, as well as active in the process of student's motivation helping them in the way it demanded and needed (De la Calle, 2004).

In this new context, the University of Castilla-La Mancha (Spain) has designed and implemented a personalized tutoring program through which each incomer student is assigned from the beginning of their college period a personal Tutor who takes care, guidance and advice to the student on all matters related to his/her academic training process such and for providing valuable information for various about a) interesting courses and seminars, b) Erasmus, Leonardo, and any other European-based grants possibilities, c) internships in Spanish companies, and d) work career and professional opportunities. These tutorials are independent from academic tutoring that each individualized teacher manages as part of teaching activities the specific content of his subjects.

The aim of this paper is to present and discuss a more elaborated Tutorial Action Plan (TAP) for students and that accompanies them during his/her academic career. Through this plan opportune training and development that complement the purely academic one will be aimed to be provided, whilst influencing areas of personality so much deep as the emotions and offering possibilities to have the control over them (Del Rincón, 2000). 


\section{MATERIAL AND METHODS}

Methods involve the development of a flexible Tutorial Action Plan (TAP) that allows the adaptation to the changing needs of students. In this context, in the Social Sciences Faculty of Cuenca in the knowledge areas of Financial Economics and Management have proposed a new TAP. The training background of these educators/professors over the years in the area of design, attention, care and responsibility in personalized tutoring is the key bases for creating such an innovative and specific TAP.

The design of TAP involves four areas. These areas, in order to draw and get a complete picture of the student's training and development process, are interested in doing an effort for easily recognize the potential weaknesses and strengths. Also, designers of this TAP are interested by providing appropriate responses to real needs and demands of students. The first area responds to the teaching-learning tutoring, of a pure teaching or academic nature (Del Rincón, 2000; García et al., 2004; Hernández \& Torres, 2005). The goal is to support and evaluate the teaching-learning-research by pondering strategies and ways of studying for each subject and/or knowledge area (Del Rincon, 2000). In this area of the TAP, academic problems of students are analyzed; the teaching content which is offered in the different subjects is completed, extended and enriched; and the study technique, career development, bibliography, sources of information and other various interesting resources are also documented and communicated (Garcia et al., 2004). The second area refers to the personalized/customized tutoring, which is focused on addressing other aspects and needs of students trying to cover areas of his intellectual, social, academic and personal activities (Garcia et al., 2004) transcending the exclusively academic one. The third area of intervention focuses on peer tutoring (Del Rincon, 2000; Garcia et al., 2004). Here, group tutorials between students in are planned to allow students perform such supervisory and mentoring/advising duties between equals. Thus, experiences, questions, concerns, and strategies of senior students can be usefully shared and offered to newbie's when they face up with same circumstances and challenges. The last area of the proposed TAP is tutoring practicum and internship activities in order to help job seeking and/or college-labor market transition process (Del Rincón, 2000; Hernández \& Torres, 2005). It is hast do to with support and advice which is provided to students when they are in a life-situation of developing professional practices in companies or close to be incorporated and participate in the labor market, especially when they are job searching in an active manner. In this final stage of the TAP the idea is to provide the students with information and training that serves for guarantee the best process of post-academic decision making.

The combination of the above four blocks constitutes a complete student information pattern with which individualized advice according to needs and preferences showed over the years by the student is provided. The follow up and track of the entire TAP process is possible through physical meetings (four times per academic year as a mandatory minimum) together with indefinite non-contact meetings also called cyber-tutoring, and that among other various possibilities can be developed through the online educational tool "Moodle Platform" provided by the Higher Education Institutions.

\section{RESULTS}

Due to the early stage of development of the TAP method proposed, the results still don't have any scientific consistency. Therefore, this tutorial plan is an educational innovation method that has a strong theoretical support but still needs more effective implementation in medium and long term. However, the following strengths and weaknesses observed during the current academic year can be pointed. 


\begin{tabular}{|c|c|}
\hline Strengths & Weaknesses \\
\hline $\begin{array}{l}\text { - The TAP is a complementary system to the formal tutorial } \\
\text { program regulated by the University. It set up an informal } \\
\text { supporting system based on trust in order to facilitate } \\
\text { knowledge sharing process between educators and students. } \\
\text { Mainly is a mentoring system where educators provide } \\
\text { knowledge, experience and guide in the decision making } \\
\text { process of students. } \\
\text { The TAP help colleges to adapt their educational plans to } \\
\text { new European ECTS education systems where educators } \\
\text { are advisers and guides in the self-learning process of } \\
\text { students. } \\
\text { This plan develops ethical principles and values to guide } \\
\text { the tutorial activity in order to create a shared value in } \\
\text { academia. It's a win-win strategy recipe where colleges and } \\
\text { students benefit from sharing the same objectives. } \\
\text { This system aims to develop and enhance student's abilities } \\
\text { (decision making, problem solving, etc.) and complements } \\
\text { its conceptual-rote learning. }\end{array}$ & $\begin{array}{l}\text { - There is some discouragement on the difficulty for } \\
\text { students to observe and interiorize immediate results } \\
\text { in his career. } \\
\text { - Loses of time in attending meetings and extra- } \\
\text { activities with this system. This fact can avoid the } \\
\text { effective implementation of this TAP method. } \\
\text { - There is an increased extra-activity for educators. } \\
\text { - Students perceive TAP as a waste of time in their } \\
\text { educational process because don't focus on core } \\
\text { educational aspects. } \\
\text { It is difficult to understand the reasons why some } \\
\text { students decide not to take part actively in the TAP. } \\
\text { It is necessary a formal agreement between two parts: } \\
\text { students and educators. When there is not such } \\
\text { agreement the TAP does not work. }\end{array}$ \\
\hline
\end{tabular}

\section{CONCLUSIONS}

The use of this designed TAP help students to achieve academic exclusivity (in order to improve their professional performance and overcoming the old student tutorial method). Therefore, the method is focused on modifying students and educator behavior (Miller, 1990; Shuell, 1986; Tolentino, 2012). In conclusion, this method involves an educational innovation from the traditional concept of mentoring university, providing students with resources and capabilities at college education in order to adapt their professional and curricular development to the current context of economic crisis and high rates of unemployment. In this new context of twenty first century the labor market is considerably fragmented, with high excess supply of labor both skilled and unskilled. As the main limitation of this paper lies in the novelty of its implementation, which will need in the future a much more robust empirical study in order to contrast if this TAP method is better than the old tutorial system.

\section{AUTHOR INFORMATION}

Raul del Pozo-Rubio is a Phd Assistant Professor of Finance Department at UCLM. His current research interests are focused on long term care costs and financing as well as tourism and environment. E-mail: Raul.delpozo@uclm.es (Corresponding author)

Pablo Ruiz-Palomino is a Phd Associate Professor of Business Administration at UCLM. His current research interests are focused on business ethics and Social Capital. E-mail: Pablo.Ruiz@uclm.es

Ricardo Martinez-Cañas is a Phd Associate Professor of Business Administration at UCLM (University of Castilla-La Mancha, Spain). His research interests are Education in Higher Education, Social Capital and Social Networks. E-mail: Ricardo.Martinez@uclm.es

\section{REFERENCES}

1. De la Calle, M. J. (2004). El Reto de ser profesor en el contexto de la convergencia europea. La formación pedagógica como necesidad. Revista Interuniversitaria de Formación del Profesorado, 18(3), 251-258.

2. Del Rincón, B. (2000). Tutorías personalizadas en la universidad. Servicio de Publicaciones de la Universidad de Castilla-La Mancha. Servicio de Publicaciones de la Universidad de Castilla-La Mancha.

3. García, N., Asensio, I., Carballo, R., García, M., \& Guardia, S. (2004). Guía para la labor tutorial en la universidad en el Espacio Europeo de Educación Superior. Retrieved January 15, 2013 from http://calidad.ugr.es/pages/secretariados/form_apoyo_calidad/docs/materialesiniciacion/tutoriauniversitariad135/! 
4. Feixas, M. (2004). De Bolonia a Berlín. Revista Interuniversitaria de formación del profesorado, 18(1), 149-162.

5. Gairín, J., Feixas, M., Franch, J., Guillamón, C., \& Quinquer, D. (2003). Elementos para la elaboración de planes de tutoría en la universidad. Contextos Educativos, 6-7, 21-42.

6. Gairín, J., Feixas, M., Guillamón, C., \& Quinquer, D. (2004). La tutoría académica en el escenario europeo de la Educación Superior. Revista Interuniversitaria de Formación del Profesorado, 18(1), 61-77.

7. Hernández, V., \& Torres, J. (2005). La acción tutorial en la universidad. Informe Técnico. Universidad Pontificia Comillas de Madrid.

8. Hernández, J. M. (1998). La nueva acción tutorial en la enseñanza universitaria. Revista de Enseñanza Universitaria, 13, 79-88.

9. Huber, G. L. (2008). Active learning and methods of teaching. Revista de Educación, núm. extraord. 59-81.

10. Martínez-Cañas, R., Del-Pozo Rubio, R. Mondéjar-Jiménez, J., \& Ruiz-Palomino, P., (2012).

Multidisciplinary case study on higher education: An innovative experience in the business management degree. Contemporary Issues in Education Research, 5(5), 349-354.

11. Martínez, M., \& Viader, M. (2008). Learning and teaching in a context of change in the university. The promotion of Teaching Team. Revista de Educación, núm. extraord. 213-234.

12. Miller, G. E. (1990). The assessment of clinical skills/competence/performance. Academic Medicine, 65(9), 63-67.

13. Quinquer, D., \& Sala, C. (2002). L'atenció tutorial a l'Autònoma: situacions i propostes. Publicacions ICEUAB.

14. Palomares, A. (2011). The educational model at university and the use of new methodologies for teaching, learning and assessment. Revista de Educación, 355, 591-604.

15. Shuell, T. J. (1986). Cognitive conceptions of learning. Review of Educational Research, 56, 411-436.

16. Toletino, M. (2012) Adaptación al Espacio Europeo de Educación Superior de las asignaturas de Finanzas en la Facultad de Derecho y Ciencias Sociales de Ciudad Real: Relación entre actividades formativas y adquisición de competencias. En J. E. Farinós Viñas \& M. D. Furió Ortega (2012). II Jornada de Intercambio de Experiencias de Innovación Educativa en Finanzas. Valencia: Universitat de Valencia.

17. Torrego, L. (2004). Ser profesor universitario, ¿un reto en el contexto de convergencia europea? Un recorrido por declaraciones y comunicados. Revista Interuniversitaria de Formación del Profesorado, 18(3), 259-251. 
NOTES 